\title{
Shift and Reduction in the Eco-Lexicon Treasures of Asahan Malay
}

\author{
Dwi Widayati $^{1 *}$, Gustianingsih ${ }^{1}$, and Rosliana Lubis ${ }^{1}$ \\ Department of Sastra Indonesia, Faculty of Cultural Sciences, University of Sumatera Utara, Medan, Indonesia \\ *Corresponding Author: Dwi Widayati*, Department of Sastra Indonesia, Faculty of Cultural Sciences, \\ University of Sumatera Utara, Medan, Indonesia
}

\begin{abstract}
This paper describes linguistic treasures presenting the environmental wealth of the Asahan Malay community and describes what factors underlie the shifting and shrinking of the ecolexicon. This description refers to Haugen's (1972) opinion pointing out three constituents in ecolinguistics. First, language exists only in the minds of its users and will function when its users relate to each other naturally as their natural and social environment. Second, the later part of the ecology is psychological: its interaction with other languages in the minds of bilingual or multilingual speakers. Third, sociological, namely the interaction with the community in its function as a medium of communication. Based on the results of the analysis it is concluded that there are many lexical treasures of river biota which are not known anymore. Likewise, some of the names of plants or parts are no longer known but some are still known with their general names due to the ignorance of their speakers and no entities found. A new and more modern pattern of settlement due to population growth in Asahan turned out to change the old way of setting up a house. The shape of the stone house but not wooden stairs began to be seen everywhere, including the house on the edge of the river. Ecolexicon hifting and shrinking in Malay Asahan language can be caused by two factors, namely internal factors and external factors. Internal factor is the depreciation of concept of understanding to the lexicon which tends to have no longer found and external factor such as (1) nature, (2) settlement, (3) environmental pollution, and so on.
\end{abstract}

Keywords: shifting, shrinking, ecolexicon, river environment, internal and external factors.

\section{INTRODUCTION}

Asahan Malay as a cultural asset of its native community is worthy to be studied in order to record how much change and shift of Malay language due to the change of living space of the language. Furthermore, the identity of the language-based community that is the heritage of the ancestors is a local power to support the diversity of Indonesian plural culture. In addition, to the rapid technology, polluted environment around the rivers and the sea have an impact on the change of language, both shift and reduction. The environmental focus around the rivers and the sea became an observation because the community of Asahan Malay speakers is in the eastern coastal area of North Sumatra.

The phenomenon that can be observed is related to the erosion of the environmental terms/lexicon since there are found many factories. The factory waste and others flow into the Asahan river and continue to various tributaries in Asahan, although efforts to overcome the waste have been done. In addition, pollution from diesel engine motorized canoes and vessels contributes to pollute the river water. Not only water pollution, but also does the deforestation erode some of the speakers' understanding of the lexicon of forest environment and brings impacts to the loss of some river biota and also the surrounding flora and fauna. As a result, some number of lexicons disappear from the native speakers' intuitions.

The proof of the vocabulary changes due to the shift and reduction of language appears in some vocabularies/lexicons which are no longer known and even no longer used by a large number of speakers. The no-longer-known lexicon or vocabulary is caused by the loss of referents referring to the naming of the lexicon. As a result, some vocabularies will disappear from their language. As mentioned above, the changes can occur due to the loss of flora and fauna species from the environment. This is caused by the contamination of the environment where the flora and fauna live. 
The loss of this symptom is specially observed in Asahan area and is concerned with the river biota along Asahan river.

Studies focusing on the shift of the vocabulary of the environment from the speaker's language as described above are linguistic studies linked to the environment or ecology. This study is called an ecolinguistic study. This study has recently become widely spoken because the role of language is very important in recording a number of regional vocabularies that are increasingly lost, reducing and even shifting due to the loss of lexicon referents and due to the destruction of the environment as the living space of the lexicon. This list of ecological lexicons is also an asset that can be passed on to the next generation to illustrate that the local language speakers once had a very rich ecological terms.

\section{METHODS}

The purpose of this study is to describe the lingual treasures presenting the environmental wealth of the Asahan Malay community and the factors underlying the shift and reduction of ecolexicon. This study is based on the concept of ecolinguistic and qualitative methods. Ecolinguistics refers to the interdisciplinary meaning of language science, which is ecological juxtaposition with linguistics or linguistics with ecology. As a discipline, ecology explains the mutual relationship between living things and the surrounding nature. So far, the study of ecology has its own appeal, especially when it is associated with other disciplines, linguistics, for example. The environment observes in particular the damage and deterioration of the environment, both the natural environment (natural) and the sociocultural environment (Mbete, 2009). ${ }^{1}$

There are three constituents in ecolinguistics. First, language exists only in the minds of its users and will function when its users relate to each other naturally as their natural and social environment. Second, the later part of the ecology is psychological: its interaction with other languages in the minds of bilingual or multilingual speakers. Third, there is sociological interaction with the community in its function as a medium of communication (Mbete and Adisaputera, 2009). ${ }^{2}$

The mutual relationship between man and the natural surroundings can be characterized by the lexicon device. In the perspective of cognitive anthropology, the set of lexicon is an important event, and activity sign in its environment (see [1]; Fill and Muhlhauser, 2001). ${ }^{3}$ For example, people in rural neighborhoods in Asahan and Tanjungbalai know sibaro (Hampala Macrolepidota), sindarsat (Oxudercinae), land 'a location away from the river', kalongkong (young Cocos Nucifera) 'young coconut that is not fleshy' and mangkabir 'bring the canoe somewhat away from river side'. The lexicon that become parts of local people's knowledge about sea characterizes the identity of the coastal community.

Diversity, interaction, and interdependence (or mutual influence and dependence) are determined as concepts of ecosystem in ecology (Odum, 1996) ${ }^{4}$ including human ecology and language ecology (see [1]). That is, humans as the users of language and environment as the space for language affect each other. Thus, the ecolinguistic study here focuses on the physically environmental changes that have direct impacts on language changes (see [3]), or language changes represent the ecological changes.

Furthermore, Mbete (see [1]) explains that if a living environment that is previously still natural, green and rich in biodiversity, such as recorded in lexicon devices and discourses on environmental resources then turns into a residential area with the diversity of buildings, towers, workshops, factories, so the surrounding rivers become chocolate flowed with waste. This also affects to the changes of the linguistic treasures of the community. Green speech turns into brown speech, even black speech.

Starting from the conception above, the function of language appears in its very clear use. A living and functioning language is a language used in a number of key areas within the socio-cultural community of its speakers. This means that if a language is no longer used or being used less, it will certainly be a sign of the death of local language (see [1]), especially, when the language is only used by the elderly people while the young people have become to use a second language, for example, the Indonesian language.

Language and social contexts in the environment of Malay Asahan native speakers become local traditional knowledge about their surrounding natural environment, that is, the expression of language is a sign of human relations and interaction with nature. Human beings record their language, 
expressions, terms, and vocabularies reflecting the lexical richness of its speakers about their community and environment. Thus, the representation of their knowledge about their environment shows vocabulary treasury that reflects the environment, both the language of the green natural environment and the language of the "brownish" natural environment. Thus, the state of the environment encoded through the language is a cultural picture they still have today.

\section{LEXICON TREASURES OF THE ENVIRONMENTAL ECOLOGY}

Understanding of the lexicons that are able to represent the social-ecological wealth of the Asahan Malay community is not easy. Here the awareness of the speaker as the owner of the lexicon is necessary to understand its history. The lexicons that are difficult to find will be easier to be forgotten by the speakers than the ones that still exist. However, even though the lexicon entity still exists, the naming for the entity has begun to shift, either by taking the common equivalent or by borrowing other terms outside the Malay Asahan language.

\subsection{Lexicon Treasures of River Biota}

The river is a source of livelihood for the Malay community in Asahan since ancient times. As a source of livelihood, it is appropriate that the surrounding community understand a number of lexicons related to the river whether it is the lexicon of river biota and other animals that live around it. Besides as a source of livelihood of the river it is also used as a pointer. Asahan Malay community does not determine direction using wind direction but using river. Four directions used are upstream (hulu), downstream (hilir), kualo, and land (darat) (see [5]).

Table 1. Lexicon Treasures of River Biota

\begin{tabular}{|c|c|c|}
\hline No. & Names of River Biota & Remarks \\
\hline 1. & Aruan (Channa Striata) & Gabus fish, found in ponds/paddy fields \\
\hline 2. & Balido (Chitala Lopis) & River fish having soft scales \\
\hline 3. & Baung(Bagrus Nemurus) & Like Mayung fish but small and having shafts \\
\hline 4. & Bittutu (Oxyeleotris Marmorata) & Like Gabus fish with spotted \\
\hline 5. & Bujuk (Channa Lucius) & Like Gabus fish \\
\hline 6. & Bulan-bulan (Megalops Cyprinoides) & Like Sepat fish but bigger \\
\hline 7. & Codong-codong & Like young Bawal fish with black scales \\
\hline 8. & Cucut (Rhizoprionodon acutus) & Like small sharks \\
\hline 9. & Giri buayo (Rhizoprionodon acutus) & Big Cucut fish \\
\hline 10. & Ketang (Scatophagus Argus) & Like Mujair fish, having yellowish shafts \\
\hline 11. & Koli $($ Clarias Sp) & Lele fish \\
\hline 12. & Kopar-kopar (Belontia Hasselti) & $\begin{array}{l}\text { The shape is circle and having the same size as } \\
\text { hand }\end{array}$ \\
\hline 13. & Lais- (lais) (Cryptopteru Spp) & Like Belida fish (thin shape) \\
\hline 14. & Limbat (Clarias Batrachus) & Like Lele fish \\
\hline 15. & Lundu (Mystus Nigricheps) & Like younger Baung fish \\
\hline 16. & Patin (Pangasius hypophthalmus) & --- \\
\hline 17. & Saludu/pangulu jamban & Small thorned fish \\
\hline 18. & Siluang (Rasbora-Borapatensis) & Small fish having black lined scales \\
\hline 19. & Siakap (Lates Calcarifer) & Like Kakap fish and having scales \\
\hline 20. & Sibaro (Hampala Macrolepidota) & $\begin{array}{l}\text { Like golden fish having red and white spots on its } \\
\text { back }\end{array}$ \\
\hline 21. & Sindarsat (Oxudercinae) & Fish living in two natures \\
\hline 22. & Sopat (Trichogaster Pectoralis) & Sepat fish \\
\hline 23. & Sopat siam (Trichogaster Pectoralis) & Sepat fish \\
\hline 24. & Sopat dayak (Trichogaster Pectoralis) & Sepat fish \\
\hline 25. & Sumbilang (Plotosus Canius) & Like Lele fish \\
\hline 26. & Sumpit-sumpit (Toxotes Jaculator) & Like younger Bawal fish, having big brindled size \\
\hline 27. & Tali-tali (Nemacheilus Pfeifferae) & Like Teri fish \\
\hline 28. & Tamonong (Restrelliger faughni) & Gembung fish \\
\hline 29. & Tapah (Wallago Micropogon) & $\begin{array}{l}\text { Like Belida/Patin fish being able to eat monkey } \\
\text { when it is at the same as pillow }\end{array}$ \\
\hline 30. & Tauman (Channa Micropeltes) & Like Aruan/Gabus fish \\
\hline 31. & Terubuk sunge & It is white and long and has many bones \\
\hline 32. & Terubuk padi (Tenualosa Toli) & Its is short (sea fish) \\
\hline 33. & Timbakul (Periophthalmus Modestus) & Like Sindarsat fish but bigger \\
\hline
\end{tabular}




\begin{tabular}{|l|l|l|}
\hline \multicolumn{2}{|l|}{} \\
\hline 34. & Tilan (Mastacembells Erytltrotaenia) & Like snake having brindled skin \\
\hline 35. & Udang (caridea) & \\
\hline 36. & Udang dop-dop (Acetes indicus) & Tiny shrimp, always in groups \\
\hline 37. & Udang gantung & Like giant prawns but smaller \\
\hline 38. & Udang putih (Penaeus Merguiensis) & Like younger shrimps but never growing bigger \\
\hline 39. & Udang galah (Macrobracium resenbergii) & \\
\hline 40. & Unam (nudibranch) & Sea snail \\
\hline
\end{tabular}

There were many lexicon treasures of the river biota whose entities can not be found today. Bittutu fish (Oxyeleotris Marmorata) is grouped in the gabus fish whose mouth looks more rounded than aruan fish (Channa Striata). Although it still has the referent, many Asahan people are no longer familiar with the name and they only mention "aruan fish". In addition, sepat fish has several variations, namely, sopat, sopat siam, and sopat Dayak but Asahan people just call it "sopat". Other fish species that begin to disappear from the speakers' reference are sibaro, kopar-kopar, and balido.

There are other types of fish, namely, badukang, balalang, bujuk (Channa Lucius), codong, dopang, dundung, giri buayo (Rhizoprionodon acutus), kalus, kapunggul, ketang (Scatophagus Argus), lais (Cryptopteru Spp), lamoduk, lundu (Mystus Nigricheps), momah, saludu (also called pangulu jamban), siakap (Lates Calcarifer), sipokar, silandit, situdong, and singe-singes. We feel hard to find their entities and young generation in Asahan has begun not to know anymore. The loss of the fish entity can undermine the understanding of the lexicons of its speaker community and do not have the concepts of meaning about such species. As a result, some lexicons are lost from native speakers' vocabularies.

\subsection{Lexicon Treasures of Plants/Parts of Plants at the River's Outskirts and Surrounding Areas}

The development of the environment or the ecology of each language may vary. In Malay Asahan, the natural environment plays an important role in the existence of a particular lexicon. The loss of the entity from the lexicon may result in the loss of the lexicon's treasury. The names of plants, for example, have begun to change. This is partly because of some reasons: they are no longer used in writing; there is alternation/shift of the lexicon to other more popular lexicons (for example in Indonesian); there is a lack of awareness of the older generation to inherit a number of lexicon towards younger generation; there are less cares about the younger generation to the environment; there is polluted ecosystem from where the plants lives.

Table 2. Lexicon Treasures of Plants/Parts of Plants

\begin{tabular}{|l|l|l|}
\hline No. & Names of Plants & Meaning/Remarks \\
\hline 1. & Asam galugur (Garcinia Atroviridis) & -- \\
\hline 2. & Aloban (Vitex Pinnata) & $\begin{array}{l}\text { The wooden stem can be used as the pole of the stage } \\
\text { house and the mast of the ship }\end{array}$ \\
\hline 3. & Bakung sunge/air (Lilium) & -- \\
\hline 4. & Bakung suaso (Lilium) & $\begin{array}{l}\text { The leaves are long and can be used to bandage broken } \\
\text { legs/hands }\end{array}$ \\
\hline 5. & Birah/dodap (Alocasia Macrorrhiza) & -- \\
\hline 6. & Bolang aRimo, pirowan (Cocos Nucifera) & The half old coconut \\
\hline 7. & Bomban (Donax Canniformis) & The nipah stalks which are peeled to bind nipah roof \\
\hline 8. & Buah nipah (Nypa Fruticans) & $\begin{array}{l}\text { Dalamnya seperti buah kolang-kaling Its inner part } \\
\text { looks like sugar palm fruit }\end{array}$ \\
\hline 9. & Buas-buas/ siburo (Premna Foetida) & -- \\
\hline 10. & Bunga oru (Hibiscus) & Asparagus flower \\
\hline 11. & Buto-buto(Excoecaria Agallocha) & $\begin{array}{l}\text { The shell looks like kedondong fruit functioning as rat } \\
\text { repellent }\end{array}$ \\
\hline 12. & Bunga aloban (Vitex Pinnata) & -- \\
\hline 13. & Bunga genjer (Limnocharis Flava) & -- \\
\hline 14. & Buluh (Bambuseae) & Bamboo \\
\hline 15. & Carome(Phyllanthus Acidus) & $\begin{array}{l}\text { This fruit is jagged rounded, rather small and can be } \\
\text { made sweets }\end{array}$ \\
\hline 16. & Cokur (kaempferia galanga) & Kencur in Bahasa Indonesia \\
\hline 17. & Dalu-dalu (Salix Tetrasperma) & $\begin{array}{l}\text { Available at river side to resist the landslide. The roots } \\
\text { are very strong }\end{array}$ \\
\hline
\end{tabular}




\begin{tabular}{|c|c|c|}
\hline 18. & Daun nasi-nasi (Sauropus Androgynus) & Katuk leaves katuk and cookesd as vegetable \\
\hline 19. & $\begin{array}{l}\text { Daun panggil-panggil (Clerodendron } \\
\text { Squamatum Vahl) }\end{array}$ & Medicine for small children loosing zeal \\
\hline 20. & Daun si kontut (Paederia Foetida) & For a spicy mixture of porridge \\
\hline 21. & Delima (Punica Granatum) & -- \\
\hline 22. & Galimayo (pandanus amaryllifolius) & $\begin{array}{l}\text { The leaves can be used as mat making materials (such } \\
\text { as pandan mat) }\end{array}$ \\
\hline 23. & Galogah (Saccharum Spontaneum) & -- \\
\hline 24. & Galo-galo (Sesbania Grandiflora) & The fruit is round \\
\hline 25. & Jariango (Acorus calamus) & -- \\
\hline 26. & Kaduduk (Melastoma) & -- \\
\hline 27. & $\begin{array}{l}\text { Kaladi gombung (Typhonium } \\
\text { Flagelliforme) }\end{array}$ & Water hyacinth \\
\hline 28. & kalapo, kalamber (Cocos Nucifera) & Coconut \\
\hline 29. & kalapo mudo (Cocos Nucifera) & Younger/green coconut \\
\hline 30. & Kalongkong(Cocos Nucifera) & Coconut that is not fleshy \\
\hline 31. & Kalayo (Erioglossum Rubiginosum) & A kind of water hyacinth but the stem is taller \\
\hline 32. & Kapal-kapal (Bryophyllum Pinnatum) & Cocor bebek which can be used for sprains \\
\hline 33. & Keladi birah (Alocasia Macrorrhiza) & A kind of taro for medicine \\
\hline 34. & Kincung (Etlingera Elatior) & A kind of plant for food \\
\hline 35. & Kumbuh (Schoenoplectus Mucronatus) & $\begin{array}{l}\text { The leaves can be used as mat making materials (such } \\
\text { as pandan mat) }\end{array}$ \\
\hline 36. & Lakum (Vitis Diffusa) & Fruit for medicine \\
\hline 37. & Lambok (Colocasia esculenta) & A kind of taro for vegetable \\
\hline 38. & Langgundi (Vitex Trifolia & For the spicy porridge \\
\hline 39. & mayaN(Rambutnyo bak mayang tarurai) & Coconut Flowers \\
\hline 40. & Namnam (Cynometra Cauliflora) & $\begin{array}{l}\text { The shape is rather small like a pastel form and it tastes } \\
\text { sour }\end{array}$ \\
\hline 41. & Nipah (Nypa Fruticans) & The leaves can be used as a roof \\
\hline 42. & Pagago (Centella Asiatica) & Also called "tapak kudo" and made for fresh vegetables \\
\hline 43. & Pandan basiang (pandanus odorifer) & Material for making mats \\
\hline 44. & Pandan berduri (pandanus utilis) & Material for making mats \\
\hline 45. & Paku sampang (Diplazium Esculentum) & A kind of fern plant \\
\hline 46. & Paku/pakis (Diplazium Esculentum) & Fern plant \\
\hline 47. & pokok kabu-kabu (Ceiba Pentandra) & Kapok tree \\
\hline 48. & Pokok piye( gramineae) & Like tall grass \\
\hline 49. & Pote cino(Leucaena Leucocephala) & In Bahasa Indonesia it is called Lamtorogung \\
\hline 50. & Pulur bomban (Donax Canniformis) & $\begin{array}{l}\text { Bomban stem that has been sharpened to bind nipah } \\
\text { roof }\end{array}$ \\
\hline 51. & Putat laut (Planchonia Valida) & $\begin{array}{l}\text { The shoots and fruit can be made for fresh vegetables } \\
\text { and they are a bit chipped }\end{array}$ \\
\hline 52. & Rongas (Gluta renghas) & $\begin{array}{l}\text { Rengas plant like putat; trees whose fruits and leaves } \\
\text { can make itchy }\end{array}$ \\
\hline 53. & Rukam (Flacourtia rukam) & $\begin{array}{l}\text { Rice that tastes sour; Redish black when it's ripe. There } \\
\text { are still found and often made sweets. }\end{array}$ \\
\hline 54. & Rukam baduri (Flacourtia rukam) & $\begin{array}{l}\text { Rukam fruit that tastes sweet; redish and black when it } \\
\text { is ripe and slightly gummy. }\end{array}$ \\
\hline 55. & Sakat(Drymoglossum Piloselloides) & $\begin{array}{l}\text { P Parasite trees (benalu) that live in the trunk of a } \\
\text { coconut tree }\end{array}$ \\
\hline 56. & Sagu (Metroxylon Sagu Rottb) & Pearl sago \\
\hline 57. & Seri (Muntingia) & Cherry \\
\hline 58. & Siponuh (Typhonium flagelliforme) & Rat taro, kind of ornamental taro plants \\
\hline 59. & Tapak leman (Elephantopus scaber) & Bowl leaves \\
\hline 60. & Temu paoh (Curcuma manga) & Types of herbs \\
\hline
\end{tabular}

Some names of the plants or the parts of plants presented in the table above are still known and some are not understood by local people anymore. The most rare species of plants are the thorned rukam (it is sweet), lakum (Vitis Diffusa) (for medicine), galimayo (Pandanus Amaryllifolius) (its leaves are used for mat-making), kumbuh (Schoenoplectus Mucronatus) (its leaves are also used for matmaking), and piyek trees (Gramineae) (they are species of tall grass). 
Some plants that produce fruits, leaves, etc. and are consumed by Asahan Asahan community are goli-goli, langgundi (Vitex Trifolia), putat laut (Planchonia Valida), daun si kontut (Paederia Foetida), tapak leman (Elephantopus scaber), and among others.

The plants that are often encountered are asam galugur (Garcinia Atroviridis), nipah (Nypa Fruticans), river/water lily (Lilium), bakung suaso(Lilium), pandan basiang (Pandanus Amaryllifolius), bomban (Donax Canniformis), siburo/buas-buas (Premna Foetida), buto-buto ((Excoecaria Agallocha), dalu-dalu (Salix Tetrasperma), panggil-panggil leaves (Clerodendron Squamatum Vahl), delima (Punica Granatum), jariango (Acorus Calamus), kaduduk (Melastoma), kalayo (Erioglossum Rubiginosum), ringan-ringan, paku sampang (Diplazium Esculentum), rongas (Gluta Renghas), and many others.

The name of the plant is now known by its more general name due to its speaker's ignorance and no more entities found. For example, kalayo (Erioglossum Rubiginosum) (a kind of water hyacinth) and kaladi gombung (Erioglossum Rubiginosum) or sometimes called enceng gondok. Younger speakers only recognize the two entities as water hyacinth. Similarly, galimayo plants (Pandanus Odorifer), cultivars, kumbuh (Schoenoplectus Mucronatus), pandan basiang (Pandanus Odorifer), and pandan berduri (Pandanus Utilis). Generasi yang lebih muda hanya mengenal dengan pandan untuk tikar (pandanus utilis). Younger generation only have the knowledge of pandan for mats.

\subsection{Leading Factors of Shift and Reduction}

Shifting and reduction of ecolexikon in Asahan Malay can be caused by two factors, namely internal and external factors.

\subsubsection{Internal Factors}

These factors include changes in the language itself, such as conceptual depreciation and internal changes. Ecological changes cause changes and synthesize the concept in the speaker's mind. Some of the changing concepts are listed below.

\section{Old Concepts}

Sopat (Trichogaster Pectoralis)

Sopat Siam (Trichopodus pectoralis)

Sopat Dayak (Trichopodus tricopterus)

Kaladi Birah ((Alocasia Macrorrhiza)

Lambok ((Colocasia esculenta))

Kaladi (caladium)

Galimayo (pandanus amaryllifolius)

Kumbuh (Schoenoplectus Mucronatus)

Pandan basiang (pandanus odorifer)

Pandan baduri (pandanus utilis)

Kalayo (Erioglossum Rubiginosum)

Kaladi gombung (Typhonium Flagelliforme)

Kapal-kapal (Bryophyllum Pinnatum)

Cocor bebek

Udang galah (Macrobracium resenbergii)

Udang dop-dop (Acetes indicus)

Udang gantung

\subsubsection{External Factors}

External factors include (1) nature, (2) settlement, and (3) environmental pollution. Unstable natural conditions make the loss of some plants and other biotas so that they can not be found anymore. As a result, the establishment of modern houses that do not have wooden stairs brings causes that various terms in the traditional homes have eroded. Moreover, environmental pollution is increasingly causing some biological, river biota, flora and fauna to lose entity. Due to the absence of a biological entity, a

\section{New Concepts}

Sopat (Trichogaster Pectoralis)

Kaladi (caladium)

Pandan tikar (pandanus utilis)

$\begin{aligned} & \text { Enceng gondok (Typhonium } \\ & \text { Flagelliforme) }\end{aligned}$
Cocor bebek

Shrimp 
number of lexicons as the names of some entities disappear in the concepts of Asahan Malay speakers.

Excessive use of forest products can be a threat to the plant species themselves, such as nipah fruit (Nypa Fruticans),, and other things related to this plant. The activity of menyomat, that is, to make the roof from nipah leaf, has rarely found because most homes have zinc or tile roof. The impact is that the term manobas 'take a palm leaf' also began to disappear from the concept of the speaker. In addition, community activities that do not care about the environment such as litter/waste disposal can contaminate and reduce the river biota. Though we know that all lexicon treasuries become local wisdom that must be maintained and documented for generations to come but sometimes we fail.

\section{CONClusions}

The treasures of many river biota lexicons can not found anymore. Likewise, some names of plants or parts of plants are still known and some are no longer known. Some names of plants are now known with general names due to the ignorance of their speakers although no entities are found. The increase of population growth in Asahan and Tanjungbalai districts brings impacts on the emergence of new dwellings. A new, more modern pattern of settlement appeas and the old way of setting up a house disappears. The shape of the stone house but not the wooden stairs are seen everywhere, including the house on the edge of the river. Shifting and reduction in Asahan Malay's eco-lexicon can be caused by two factors, namely internal and external factors. The first include the depreciation of concepts and the last covers (1) nature, (2) settlement, and (3) environmental pollution.

\section{REFERENCES}

[1] Mbete, Aron Meko. 2009. "Selayang Pandang tentang Ekolinguistik: Perspektif kelinguistikan yang Prospektif' Bahan untuk Berbagi Pengalaman Kelinguistikan dalam Matrikulasi Program Magister Linguistik Pascasarjana Universitas Udayana, 12 Agustus 2009.

[2] Mbete, Aron Meko dan Adisaputera, Rahman. 2009. "Penyusutan Fungsi Sosioekologis Bahasa Melayu Langkat pada Komunitas remaja di Stabat Langkat." Makalah Seminar.

[3] Fill, Alwin and Peter Muhlhauser (Eds). 2001. The Ecolinguistics Reader: Language, Ecology, and Environment. London and New York: Continuum.

[4] Odum, Eugene P. 1996. Dasar-Dasar Ekologi. Edisi ketiga. Terj, Tjahyono Samingan. Yogyakarta: Gadjahmada University Press.

Citation: Dwi Widayati, et al. "Shift and Reduction in the Eco-Lexicon Treasures of Asahan Malay". International Journal of Humanities Social Sciences and Education (IJHSSE), vol 4, no. 11, 2017, pp. 85-91. doi: http://dx.doi.org/10.20431/2349-0381.0411010.

Copyright: ( $) 2017$ Authors. This is an open-access article distributed under the terms of the Creative Commons Attribution License, which permits unrestricted use, distribution, and reproduction in any medium, provided the original author and source are credited. 